Article

\title{
Implementation of Circular Economy Principles in Industrial Solid Waste Management: Case Studies from a Developing Economy (Nigeria)
}

\author{
Obiora B. Ezeudu ${ }^{1, *(1)}$ and Tochukwu S. Ezeudu ${ }^{2}$ \\ 1 Centre for Environmental Management and Control, University of Nigeria, Enugu Campus 410001, Nigeria \\ 2 Institute for Development Studies, University of Nigeria, Enugu Campus 410001, Nigeria; \\ tezeudu@gmail.com \\ * Correspondence: obiezeudu@yahoo.com; Tel.: +234-080-60828002
}

Received: 18 September 2019; Accepted: 18 October 2019; Published: 21 October 2019

check for updates

\begin{abstract}
The existing solid waste management principles are increasingly being replaced with discussions on circular economy (CE) principles in contemporary deliberations on solid waste handling. This shift is supported by the global adoption of the concept of sustainable development. The CE offers better prospects to solid waste management and has been implemented successfully in its full theory, practice, and policies in some developed locations of the world. The socio-economic disadvantages, insufficient expert knowledge and a lack of information have hindered its appropriateness and implementation in low and middle-income countries. Hence, the current research study examines the challenges and opportunities of implementing the circularity principle at the industrial sector level of a typical developing economy-Nigeria. Four different industries were selected for this case study - telecommunications, water packaging, pulp and paper and the food industry. These industries represent the major waste streams in an urban solid waste mix (waste electrical and electronic equipment (WEEE), plastic, paper and organic). This study discovered several barriers and existing pre-conditions in place that could either foster or militate against the smooth and successful application of a CE model as a simple modification of the generic model. This study also discussed future directions on the implementation of the model.
\end{abstract}

Keywords: circular economy; developing economy; waste management; environmental policy; sustainability; Nigeria

\section{Introduction}

The circular economy (CE) is a recent and growing area of research that advocates for a regenerative approach to natural resource management, as opposed to a linear method that is hugely unsustainable as a result of the finite availability of raw resources for production and the associated environmental degradation [1]. The circularity principle is being further propelled by the overarching issue of sustainable development, which has caught global attention and adoption. Based on this perspective, this area of research has become a topic of interest for many researchers in recent times, especially in the specific areas of waste valorization, cleaner production, life cycle thinking and green consumption. To date, managing solid waste in most world cities has traditionally followed the implementation of a linear economy system. Although this approach emphasizes integrated approaches to waste handling in order to protect the environment and public health, the central focus of this system is usually to ensure that the generated waste does not cause harm to the environment, humans and the society at large [2]. Hence, it proposes the handling of waste according to hierarchies, which means seeking the best waste disposal method and resorting to the second-best alternative when the first 
is not feasible and so forth. Although it encourages waste minimization, recycling and re-use at all costs, the overall motive and intent are to manage waste resources with the focus on environmental protection. However, it is not often linked to business and economic possibilities [3].

Several nations of the world have moved from the implementation of traditional waste management practices and policies and have fully adopted CE principles $[4,5]$. The majority of these countries share commonalities in terms of viable economic status, advanced technologies, strong political will, credible public governance and state-of-the-art public infrastructure. This has raised the issue of the capability and eligibility of low- and middle-income countries in adopting the same CE in its full theory, practice and policies. The additional factors that result in the non-adoption of CE in Africa are the lack of knowledge on the implementation processes and the absence of information [6,7]. The practical benefits of CE adoption have been widely reported at national, sub-national and local government levels and even in the economic sectors in the countries where they are currently in practice, whereas $C E$ is still a relatively new concept in developing countries with the exception of G20 countries, such as China [8-10]. As the lack of knowledge on how it can be implemented has partly hindered most African countries from adopting the concept, this suggests that research efforts should offer direction in this regard [9]. thus, the reason for this research. The current work looks at the possibilities of CE application in solid waste management at an industrial level in Nigeria-a typical developing country. The majority of the waste management policies in the country are qualitative in nature and are often devoid of scientific, business and economic merit, which is partly the reason for their failure. Therefore, it has become necessary to integrate the CE principle into the formulation and implementation of these policies and practices in order to ensure positive outcomes. To the best of the authors' knowledge, no work has analyzed the industrial solid waste management system in Nigeria with the aim of proposing a CE solution. Hence, the aim of this work is to analyze the policies and practices of industrial solid waste management in Nigeria and to also evaluate the prospects, challenges, barriers, and opportunities for implementing the CE in the country's industrial solid waste management. This current work does not consider the hazardous waste generated by these industries.

The current work adopts a case study methodology. Four industries were selected as a case study: the telecommunication industry, food industry, pulp-paper industry and water packaging industry. This was done to represent the major waste stream characteristics of a typical municipal solid waste constituent-WEEE, plastic, paper, and organic waste. In the first section of this work, the general background of the study is presented, including the socio-economic status of Nigeria, the industrial development background of a developing economy and an overview of the county's solid waste management practices is discussed. In the second section, the study methodology is explained. The research findings are discussed in the third section while the future directions and opportunities are provided in the fourth section.

\section{Literature/Theoretical Framework}

\subsection{CE in Solid Waste Management}

The CE as a concept that is currently trending in the global research arena and it has garnered considerable attention among scholars as well as being adopted by institutions, policymakers, and other key economic sectors. This can be attributed to its uniqueness in articulating a restorative and regenerative approach to resource administration as opposed to the traditional linear model [1]. The concept focuses on the product and is commonly applied at the design, production, consumption and waste management stages [11].

In the area of waste resource management, the existing solutions tend to view waste products as a nuisance that constitute negativities to the environment, natural resources and public health therefore, solutions have been proffered bearing this in mind. Furthermore, in the linear economy model, solid waste handling modalities view waste products as a problematic commodity that often entails the deployment of scarce resources to manage them. In most developing countries, waste 
management is seen as an essential service to the citizenry and therefore, municipalities carve out a substantial part of their annual budget for solid waste management without projecting any significant return on the investment [12]. Even when a public-private partnership is deployed, the aim is often to maximize revenue collection from the public to ensure effective waste management services such as collection, transportation, and disposal [13]. However, the CE model promotes the concept that a product that has been perceived to have reached its end-of-life in a particular system might be used as a raw material in another or the same system, as shown in Figure 1. The circularity principle further reframes the traditionall viewpoint by considering waste products as resources that could have an endless or multiple lifespans, with economic, social and environmental gains [14].

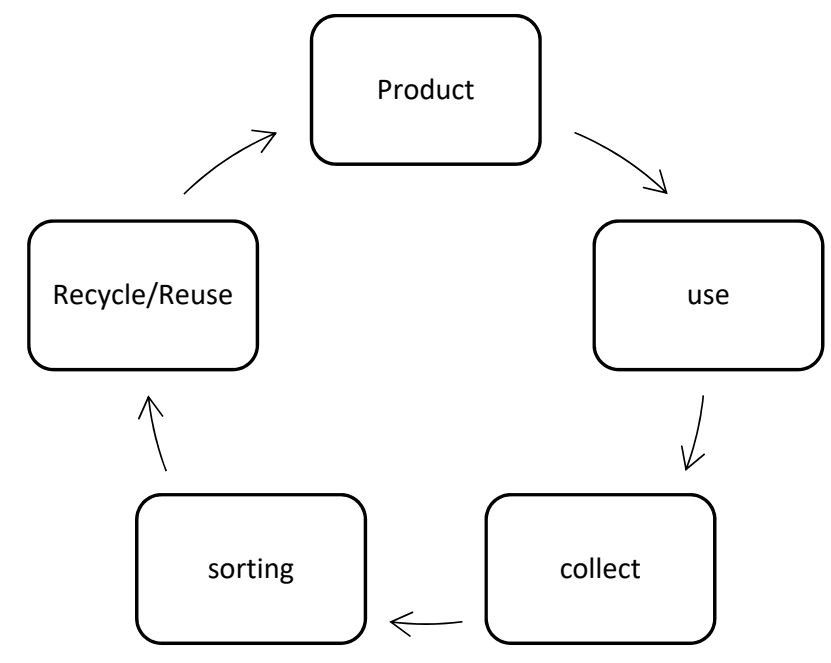

(a) The circular economy (CE) Model

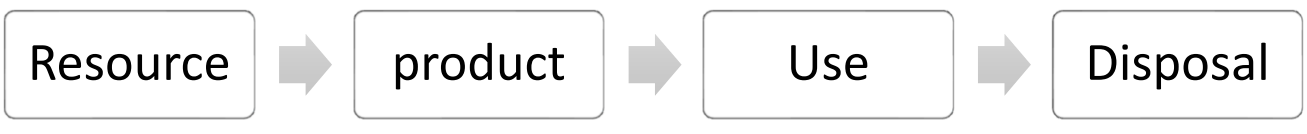

(b) Linear economy model

Figure 1. Circular economy (CE) model versus Linear economy model. (a) is labelled CE model and (b) linear economy model.

Socially, adapting the CE model can generate employment and foster greater social inclusiveness of the general public in environmental management. Economically, it can generate wealth and minimize the cost of production, while environmentally it ensures the optimal use of natural resources while abating pollution.

According to some explanations, the linear economy model leads to the inefficient use of scarce resources, increases harmful emissions and yields increasing amounts of waste from the entire value chain including the extraction of resources, manufacturing, transportation, and consumption [15]. Therefore, expert consensus in favor of $\mathrm{CE}$ is based on the fact that the intrinsic mechanics of the linear economy operates on the wasteful take-make-disposal flow, which is not only detrimental to the environment but cannot supply the growing populace of our planet with essential services and it naturally leads to strained profitability $[16,17]$. However, it is crucial to mention that because CE is still an evolving concept that lacks an extant body of theory, some have challenged its effectiveness, for instance, in optimizing the organizational cost when it is holistically evaluated with regard to the transaction cost of contracts, the reconfiguration cost for resource portfolio and influences on the business network [18]. Other areas of possible weakness in the CE have been highlighted, including its thermodynamic limitations, the unclear definition of $\mathrm{CE}$ system boundaries and the challenges 
pertaining to the governance and management of CE-type inter-organizational and inter-sectorial material and energy flow [19]. However, the growing popularity of the CE concept is essentially due to its influence on the sustainable development concept in two key areas of economic prosperity and environmental quality [20]. However, even the opposing views rightly agree that CE as a concept has significant merit based on its ability to draw the business community, policymakers, and governments to sustainable development work [19]. Meanwhile, for the efficient and comprehensive implementation of $\mathrm{CE}$, efforts are required at three levels which include the micro-level (enterprises, factories, and production outfits), meso-level (eco-industrial park and inter-firm level) and macro-level (provinces, regions, states, and cities) [7]. This is in rhythm with the sustainable development objective that emphasizes cooperation of multi-levels-local, national and regional—in a formal partnership towards combating the world's problems together [9]. Nevertheless, recent studies have suggested that theoretical CE models could be proposed prior to the evaluation and subsequent adoption by the socio-economically disadvantaged nations in the frugality context. This is a confirmation that CE models can be flexibly applied considering the fact that cities and societies could differ in the socio-economic, political and even cultural context [21]. In this vein, a theoretical CE model was proposed by Ferronato et al. [21]. The work studied municipal solid waste management systems in two developing countries of Romania and Bolivia and proposed a trimmed down (from the standard) CE model to the suitability of the studied countries. Like most developing countries, waste management policies, practices, and regulations in Nigeria have not been adequately developed and the existing ones are poorly implemented [22]. Most policies that involve solid waste management in industries were mainly articulated and implemented as an integral part of the general urban solid waste management system. The aftermath is rightly reflected in the poor state of solid waste management in the country.

\subsection{Industrial Development: Developed vs. Developing World}

Historically, industries in developed countries have evolved over time as a result of breakthroughs in science and technology. For instance, the nineteenth-century industrial revolution in Europe was as a result of the discovery of coal as a primary energy source which replaced firewood and created an avenue for the invention of coal-fired power plants and train systems that facilitated mass transportation and other industrial activities [23]. To some extent, industrial development and revolution in developed societies could be tied to successes in scientific research and development which created a platform for orderliness and the systematic transition from one industrial age to another. In line with this, industry 4.0 (the 4 th industrial revolution), which is the latest production paradigm, has already been proposed and is currently being discussed for possible adoption [24].

However, the industrial development approach in developing nations, especially in sub-Sahara Africa, has been different, unconventional and most times erratic. Industries appear unconventionally and blossom as a result of the huge low-income population, large and vibrant informal sector and the criticality of the societal problem that the emerging industries solve. A typical example is the telecommunications industry in Nigeria. This industry has thrived and contributed immensely to the socio-economic development of the people, despite the poor status of energy supply infrastructure in the country. A further example is the water packaging industry in Nigeria which has grown greatly as a result of the criticality of their products and services to the general masses sanctioned by the failure of the government in providing the standard traditional water supply services to the citizens $[25,26]$.

On the other hand, opinion has been conveyed that firms and industries, both in developing and developed societies, are ever willing to embrace circular and sustainable business models in order to attain commercial differentiation, a competitive advantage and potential growth with economic benefits and hence, require expert support towards this objective [14,27]. It therefore becomes necessary that the CE waste management model that should be adopted by the industries operating in the developing economies be designed to reflect the unconventional business models under which they originate, operate and thrive. This point is considered in the current study. 


\section{The Study Area: Nigeria}

\subsection{Socio-Economic Status}

Nigeria is a developing West African country with enormous prospects specifically in the areas of natural resources and human capital potential. It has a great endowment in crude oil and natural gas, solid minerals, vast and suitable land for agriculture and water and forest resources [28]. The population of Nigeria has been approximated at 198 million people as of 2018, calculated with $3.2 \%$ annual population growth index and also based on the 2006 population census figure of 140,431,790 [29]. However, the country's rich endowment in natural resources somehow has facilitated enormous economic prosperity, such that it has been consistently rated among the largest economies in sub-Sahara Africa since 2004. Further speaking of potential, Nigeria and China share many similarities when measured against ethnic diversity, mineral and human resources [30]. For instance, China is the largest single market in the world, while Nigeria is the largest single market in Africa. However, the difference is that China has been able to exploit its vast demographic, human and natural resources to build a strong and virile domestic economy which has positively affected its citizenry [31]. In the exact term, China has lifted approximately 662 million people from poverty since 1981 through various economic reforms [32]. Nigeria in its own case is currently contending with enormous social-economic challenges, such as a high unemployment index, technological backwardness, an underdeveloped agricultural sector and per capita poverty index. Hence, Nigeria was recently rated the poverty capital of the world. Drawing on this comparison, CE as a policy has been successfully adopted and implemented in China at various levels [7], while Nigeria is still struggling with monumental solid waste management challenges.

\subsection{Current Waste Management Framework in Nigeria: Brief Overview}

A major milestone in solid waste management in Nigeria came with the establishment of the Federal Environmental Protection Agency (FEPA) in 1988 [22]. The FEPA was later merged with other key government agencies to form the Federal Ministry of Environment in 1999. The responsibility of this ministry is to issue guidelines on how key environmental issues, including solid waste management, should be tackled. However, the task of making laws, implementations and enforcement mostly lie on the state governments through various state ministries of the environment and municipal councils. The guideline on solid waste management in the country was released in 2005 by the Federal Ministry of Environment. The policy document recognized the fact that strategies for waste management at the grassroot level should interface with the local culture, land use type, economic base, climatic condition, existing urbanization level and institutional arrangements [33]. The guideline, however, was not detailed on each aspect of solid waste management, such as waste reuse, recycling, and final disposal techniques. Furthermore, it did not create room for updating based on issues that might arise in the future, such as the issue of informal recycling activities [28]. Another major setback is that the ministry's guideline recommends landfilling as a method of final waste disposal but was silent on the modalities for landfill construction and operation, whether at the present or in the future. However, a recent study has demonstrated that many landfills in developing countries (Nigeria inclusive) are non-engineered, which makes it quite difficult to harness the waste resources into valuable products for commercialization [34].

Due to these inconsistencies, studies further reported that approximately $68 \%$ of the solid waste generated by communities in Nigeria are indiscriminately dumped, barely $21 \%$ is disposed of through landfill sites and $11 \%$ are burnt $[35,36]$.

However, Nigeria has over 5000 industrial facilities and over 10,000 small scale industries [37]. Most of the waste generated by these small and medium industries are managed along with municipal solid waste (as shown in Figure 2) without any special guidelines that take into account the nature, quantity and variant of the waste generated by each distinctive industry [2].There has been significant pressure on the industry regulatory bodies in Nigeria to formulate specialized industrial guidelines 
that would not lead to confusion and conflict as per the roles, objectives, goals, purpose, of the various stakeholder involved [38]. For this reason, it is proposed that the first step to offering a sustainable solution to the country's solid waste management crisis is to regulate waste according to the generating industry by internalizing policies and regulations in CE ideology and hence, the need for this study.

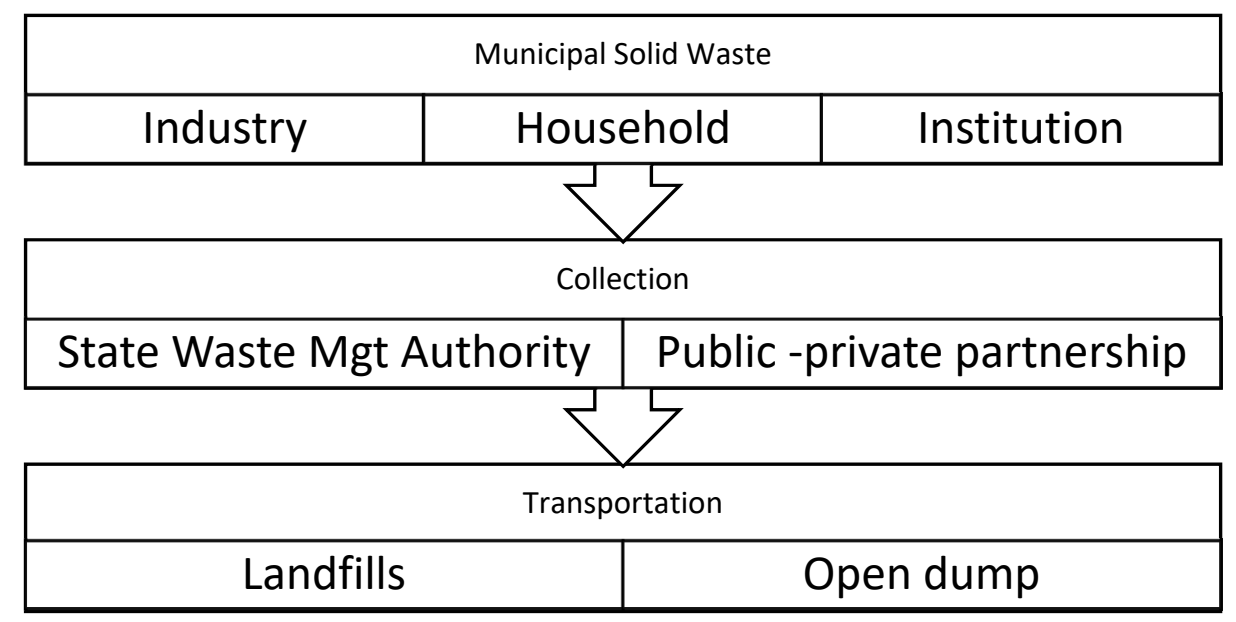

Figure 2. Current waste management framework in Nigeria.

\section{Materials and Methods}

\subsection{Case Selection}

Three industries were selected for the study using purposive sampling methodology - telecommunication industry, food industry, and water packaging industry. The pulp and paper industry was included based on recent comprehensive work on paper waste management and practices in Nigeria [See 28]. The solid waste from the selected industries represents a major stream in the country's urban solid waste mix which includes organic, plastic, paper and WEEE. The purposive selection was done in conformity to information-rich cases [39]. The selected industries are information-rich in the following context: economic viability, versatility, geographical coverage, and robustness within the study area (Nigeria). Above all, they are rich in the features known for a thriving typical industry in a developing market economy as mentioned in Section 2.2. In essence, much could be learned about matters of importance and is therefore worthy of in-depth study.

\subsection{Data Collection}

The standard and documented data on solid waste management in most sub-Sahara African countries (including Nigeria) are not available [12]. The current study adopted a qualitative research method for data collection. Further reasons for adopting the current methodology include: (i) Quantitative measurements or survey-based methodologies are either inappropriate or less preferred for assessing organizational processes, such as industrial waste management processes [40-43]. (ii) Specifically, when the aim of the study is to gain an understanding of the richness and complexity of the phenomenon, quantitative methods, such as experimental and survey methods, are less capable of capturing the details and providing insights, which makes a qualitative method more appropriate [43,44]. (iii) Exploratory fieldwork is important in a new area of research (circular economy) that lacks an established body of theories and data $[43,45,46]$. (iv) The use of case research allows concepts to be developed for further study $[45,46]$. (v) The case study research approach helps in developing a thorough understanding of how things work rather than testing hypotheses that are derived based on existing theory [42]. The data required for the study were collected through three main sources: (i) Documented evidence through, academic peer-reviewed journals, company websites, financial reports, policy briefs, government publications, magazines, newspapers, and other relevant 
grey publications; (ii) semi-structured interviews were also conducted on the selected respondents from the four industries in order to capture information that might not be available in the reviewed materials; (iii) observation through exploratory fieldwork. The multiple sources of data collection are to meet the basic criteria for construct validity in case study research. The current study, therefore, applies a descriptive case study method to examine the current solid waste practices in the selected Nigerian industries. The data obtained from the different sources were triangulated, revealing a high level of consistency $[40,47,48]$.

\subsection{Case Description}

The four case reports are described in this section. In each industrial sector, the findings from the analyzed information with regard to current practices, issues, challenges, and opportunities were described. A summary is shown in Table 1.

Table 1. Summary of CE attributes of the selected industries. Source: The authors' collection.

\begin{tabular}{|c|c|c|c|c|}
\hline Attributes & Telecoms & Food Industry & Water Packaging & Pulp and Paper \\
\hline Institutions & Exist & Exist & Exist & Nil \\
\hline SWM Policies & Exist & Nil & Nil & Non-Exist \\
\hline Recyclable/Reusable & WEEE & $\begin{array}{l}\text { Food waste, PET bottles, } \\
\text { nylon sachet, Metal cans }\end{array}$ & $\begin{array}{c}\text { PET bottles, nylon } \\
\text { sachet }\end{array}$ & Paper Waste \\
\hline Informal waste activities & $\begin{array}{c}\text { Refurbishers, } \\
\text { Informal Recyclers }\end{array}$ & $\begin{array}{c}\text { Dog Breeders, Informal } \\
\text { Recyclers }\end{array}$ & Informal Recyclers & Informal Recyclers \\
\hline Waste disposal & Govt. Agency & Govt Agency & Govt Agency & Govt. Agency \\
\hline
\end{tabular}

\section{- Telecommunication Industry}

Although mobile telephony was introduced in Nigeria in 1992, competition in fixed telephony through licensing of fixed telephone operators started in 1997 [49]. The major breakthrough in the Nigerian telecommunication industry took place in 2001 with the licensing of four digital mobiles (GSM) operators through auction. Following this event, as of 2006, Nigeria was rated among the fastest growing telecommunications industry in the world [49]. Currently, the Nigerian telecommunications sector is the largest in Africa and has made an enormous contribution to the economy and the social well-being of the citizenry [50]. Precisely, the industry contributed $\$ 21$ billion dollars to the country's GDP (Gross Domestic Product) in 2017, which represents 5.5\% in fraction of the total GDP and 10.1\% in the first quarter of 2019. While approximately $16 \%$ of the government's tax revenue amounting to $\$ 1.8$ billion came from the sector [51]. The telecommunications industry in Nigeria along with the ICT (Information and Communications Technology) sector provided approximately 2.5 million jobs in the country in a period of 10 years [52]. The vast number of this employment is indirectly created in the informal sector engagements.

The problems of e-waste management in Nigeria, such as the absence of waste infrastructure, the absence of specific legislature and the absence of modalities for the end-of-life product retract the implementation of extended producer responsibility (EPR) [53], which may have started at the onset of current telecommunications revolution in the country. Therefore, there were no significant pre-existing issues of e-waste management until this era, in the form of policies, institutions or even research efforts. As of 2018, Nigeria has 97.5 million unique mobile subscribers, $49 \%$ mobile penetration (projected to reach $55 \%$ by 2025), 151 million total connections and 53 million smartphone adoptions (projected to 144 million by 2025) [51]. GSMA (Global System for Mobile Communications Association) also reported in 2018 that the mobile network connects more Nigerians to the internet than any other technology and has more primary platforms for creating, distributing and consuming digital content and services across multiple sectors [51]. This means that by extension, the telecommunications industry constitutes the major facilitator of e-waste generation in the country. The environmental impact linked to the production and disposal of electronic gadgets is aggravated by their limited lifespan, which mounts pressure for an increase in the production and adversely leads to an upsurge 
in the number of WEEE going to landfills or recycling [54]. In 2014, it was reported that 219,000 tons of e-waste were generated in Nigeria [55]. The majority of this waste was recycled and/or usually processed by backyard industries under the most primitive of processes [56,57].

Another important factor is that the advancement in telecommunications in Nigeria depends to a large extent on second-hand/refurbished electrical and electronic equipment [53]. Lagos, a major Nigerian city has approximately 5500 small businesses in the field of refurbishing and marketing used electrical and electronic products [58]. In fact, the electronics refurbishing sector in Lagos has developed into a regional hub that does not only serve Nigeria with second-hand products, but also the neighboring West and East African countries [58]. Therefore, Nigeria could be said to have a viable informal recycling sector on WEEE. The report also shows that, overall, more than 100,000 people work in the informal e-waste recycling in Nigeria [38]. They collect and dismantle WEEE by hand to retrieve the saleable parts. The other parts with no salvaging value are often dumped along with the urban solid waste or burnt [38]. Further, $75 \%$ of the second-hand electronics imported into the country are either non-repairable, toxic or obsolete and are moved straight to dumpsites, landfills and/or dismantling outfits [38]. Recognizing these challenges, the Nigerian Communications Commission (NCC), a statutory body charged to oversee the industry, issued the Nigerian Communication Industry E-waste Regulation in 2018 [59]. This policy document is an attempt to specify the responsibilities of each player in the e-waste generation, collection, and disposal across the country, such as manufacturers, vendors, importers, consumers, recyclers, bulk consumers, etc.

\section{- Food Industry}

The Nigerian food industry was estimated in 2016 to be worth over 1 trillion naira with the quarter of the value arising from the fast food sub-sector. It has also been highlighted as the most economically-healthy and best-performing industry in the country, in spite of harsh economic conditions [60]. The number of food processing companies in Nigeria has increased over the years and by extension the number of products [61]. As of 2010, approximately 17 industrial food processing sub-sectors comprising of over 5000 companies are involved in food processing and production in Nigeria [62]. This work concentrates on the fast-growing fast food industry that litters extensively in Nigerian streets, the majority of which are classified as the informal sector. This also includes street foods which according to the Food and Agricultural Organization of United Nations is defined as ready-to-eat foods and beverages prepared and/or sold by vendors and hawkers, especially in streets and other public places [63]. In the Nigerian context, it is difficult to differentiate between this street informal food and formal restaurants as the patronage are no longer determined by social factors, such as income or earning.

The industry generates enormous organic waste material that is mostly disposed of along with municipal solid waste in most cities in the country. This is evidenced in the fact that none of the the existing reviews on municipal solid waste characterization in Nigeria have failed to highlight a significant portion of food waste as constituents [64]. Due to the poor power supply infrastructure in the country, large quantities of food items prepared by these industries cannot be reasonably preserved longer and hence, are meant to be consumed almost immediately. This is an indicator that a large quantity of food material could be wasted within this industry. The fast foods serve ready-packaged water in either plastic bottles or nylon sachet, plastic and metal canned beverage drinks. The solid waste generated in these industries is dominated by the three waste stream characteristics:- organic, plastic bottle, plates and nylon sachets. There have been policy efforts towards regulating the general operation of this industry in Nigeria, but most of these efforts concentrate on environmental sanitation and hygiene of the operating surroundings. The solid waste management in this industry is left to follow the general urban solid waste management guidelines in the urban areas. Notably, a considerable amount of undocumented informal waste recycling activities are continuing within this industry, as one of the interviewed respondent noted as follows; 
(i) "The organic solid waste (food leftover) generated in the fast-foods is increasingly being sought for by city's dog breeders. Dog breeding is a growing business in most urban cities in Nigeria and has employed the majority of youths."

(ii) "The plastic bottles so generated are increasingly no longer seen as a waste by the food vendors. Because of its reusable and recyclable values, the food vendors collect them at the end of each day and sell them back to the scavenger for additional profit".

(iii) "The effort at collecting back the used sachet plastic nylon has not been significantly noticed among the food vendors or scavengers." The sachet nylon waste is usually disposed of as a component of municipal solid waste for onward movement to open dumpsites or landfills, as the case may be. The most cogent explanation for this is likely there are neither market outlets nor the incentive for salvaging them [65].

\section{- Water Packaging Industry}

Due to the high technological costs experienced by governments, the standard industrialized world model for safe drinking water delivery seems expensive in most of the low and middle-income countries [26], which has resulted in a shortfall in the provision of adequate safe drinking water for the populace. The Nigerian private sector, motivated by profit and armed with entrepreneurial spirit and capabilities, engaged in frenzied activity to provide portable and affordable water to the Nigerian society. They provided an alternative to the non-performing urban pipe-borne water supply in the form of sachet water, known as pure water in Nigeria (See Figure 3) [25]. They also produced bottled water. Pure water in Nigeria is readily available and the price is affordable. The domination of these two product variants in water provisioning in the country has proved its market viability and social acceptability among all the income classes in the country. In a typical, dry season, it has been reported that roughly $70 \%$ of Nigerian adults drink a sachet water a day [66]. This translates to approximaetly 50 to 60 million used sachet nylons disposed of across the country each day. Sachet water has become a very important source of drinking water to many households across the country, both in the urban and rural areas [67]. The exact time of the introduction of sachet water into the Nigerian market is not known, but the literature suggests that the water packaging method started around the 1990s. Furthermore, sachet water came into prominence in the year 2000 when National Agency for Food and Drug Administration and Control (NAFDAC) recognized the operators by issuing them with operating licenses $[25,26]$. The activities of the industry have been largely regulated by the agency with greater emphasis on water quality, sanitation, hygiene practices and standard operating procedures. The agency, however, does not regulate the management of solid waste that the industry produces. The solid waste from this industry in the form of sachet nylons and plastic bottles is a common sight on the Nigerian streets and overfilled bins in the city waste bins. The packaging material for this sachet water is made of a non-biodegradable synthetic polythene. While the used plastic bottles have been recently in high demand among the scavengers, little effort is being made to collect and recycle the waste sachets nylons [65]. The collected used plastic bottles could be sold at both primary and secondary markets. At the primary markets, they are sold to the producers that buy them in bulk for reproduction whereas in the secondary markets, they are sold to users that reuse them for many alternative purposes such as containers for oils, fuels, food items, etc. No known laws and policies exist on the collection of these materials by the producers. The uncollected waste of sachet nylons or plastic is combined with the municipal solid waste and disposed of in either open dumpsites or in a landfill. 


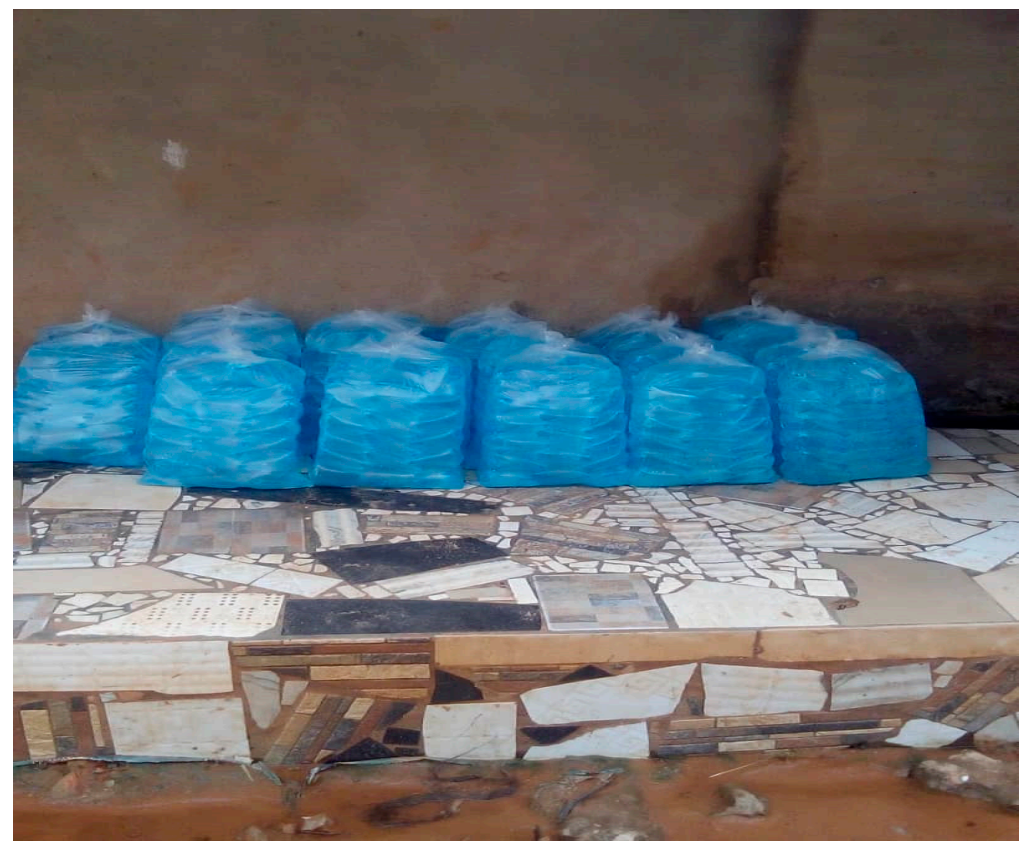

Figure 3. Packaged pure water from the factory.

\section{- Pulp and Paper Industry}

As at 1970s and 1980s, Nigeria still had a viable paper and pulp industry which, at its optimal performance, could satisfy domestic paper demand in the country. However, the collapse of the government-owned integrated paper mills was due to factors largely attributed to the unavailability of long-pulp fiber in the Nigerian forest. Since that time, there has been an incredibly large dependency on imported pulp and finished paper material across the country. Further, local paper production in Nigeria has been experiencing enormous challenges [28]. Currently, the paper consumption and demand across the country have been on the increase and this demand is mostly met through importation. The Raw Material Research and Development Council is a paramount government agency responsible for advising the government on alternative sources of local material for sustainable industrial growth. The council once attributed this high demand and consumption of paper and paper products in Nigeria to the Universal Basic Education (UBE) scheme embarked on by the federal government to improve the literacy level of Nigerians [68]. On the other hand, a variant of paper products popularly called tissue or toilet roll in Nigeria has also been in high demand and consumption due to its essential use in sanitation and hygiene. This product has been tagged among the fast-selling and most profitable products in the country and its production depends more on recycled fiber than virgin fiber materials. However, there has never been any popular policy or practice designed for optimal recovery of paper waste in the country for onward recycling.

The large volume of paper and paper material generated across the country is either burnt in the backyard, buried in the landfills or in an open dump across the country [28]. Informal paper recycling has been reported to be in practice in Nigeria, where due to economic hardship, households and offices store up used newspapers for sale to scavengers when the value is perceived to be high [13]. Furthermore, there is a practice of reusing paper for secondary alternative purposes such as the wrapping of food items, gift material and for other packaging purposes. These practices exist in the country but without any formal data documentation. No independent government agency is solely responsible for the regulation of the paper and pulp industry in Nigeria. As part of the general industry, the pulp and paper industry follows the general industrial guideline as issued by the National Environmental Standards and Regulations Enforcement Agency (NESREA). 


\section{Findings and Discussion}

The research data was analyzed using the iterative process of case comparison and the results are discussed below.

In the four cases described (with the exception of telecommunications), there was an absence of specialized industrial-level policies, regulations or even campaign exercises on the ways of managing the solid waste generated by these industries. However, in all the industrial cases, with the exception of the pulp and paper industry, there is an independent regulatory body or agency that oversees the affairs of the industry. For example, NAFDAC and Standard Organization of Nigeria (SON) for food and water packaging; NCC for telecommunications. The current opportunity is that the existing institutional framework has created a subtle platform for the introduction of CE policies for the regulation of solid waste generated in the industries. These industrial regulators may have existing databases of the registered firms and their addresses which makes it convenient for the introduction of the policy, implementation, and monitoring of compliance. NESREA is responsible for the general environmental standard regulation of the entire Nigerian industrial sector, but it has been constantly argued that the agency lacks human resources and the capacity to efficiently perform these multiple functions [28]. Recognizing the importance of distinctive industrial policy measures, the NCC has already drafted a guideline in this respect in 2018 [59]. While this is a good starting point, the drafted guideline by the NCC is replete with qualitative edits upon which its enforcement depends. It is lacking in some basic principle, practice and theory of the $\mathrm{CE}$ that recognizes waste as a means of wealth creation. For instance, there were no incentives for e-waste collection and recycling and the informal collection was not recognized or promoted as an important party to e-waste management as it is obtainable in most developing economies as presented in Table 2 [21]. Furthermore, NAFDAC has a strong guideline and regulatory framework for food and water administration in the country in terms of standard operating guidelines, but with no known CE programme as regards to the solid waste produced by the industry.

Table 2. The components of Nigerian Communications Commission (NCC) Policy Guidelines on E-waste Management in Nigeria. Source [59].

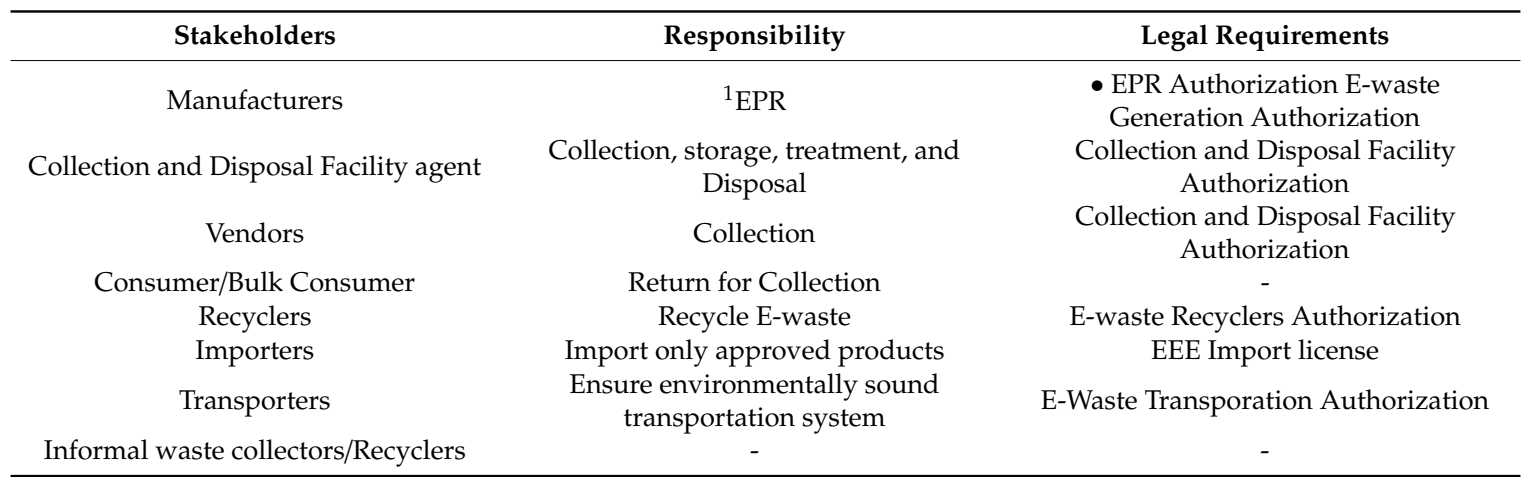

${ }^{1}$ Extended Producer Responsibility.

The study findings also revealed a considerable amount of informal waste picking activities present across the industries. Previous studies have noted that a large number of scavengers migrate from rural areas to urban areas for this purpose, especially during the dry season (non-farming season) [65]. They pick metal scrap, plastic waste material and WEEE for onward sale to the middlemen or whole seller who bulk-sells them to the small and medium scale industries that make use of them. Their operation is motivated by profits and harsh economic conditions. However, the activity is haphazardly practiced with little or no government recognition or regulation [13]. In the food industry, the food waste and leftovers being a new development among the recyclable material may not have caught the attention of many scavengers and hence, have not been widely collected across the country. According to one of the food vendors interviewed, she noted that, "We sometimes give them out to our customers at 
no fees, so far it has relieved us of the stress of evacuating the waste. The customers that demand or buy them is not usually a professional scavengers per se, but regular people, so, therefore, there is no standard transactional method or fixed price".

A large volume of used PET (Poly-Ethylene Terephthalate) bottles are generated and collected at both food and water industries by the vendors and sold to scavengers or to direct secondary buyers. The telecommunications industry seems to have a more organized informal recycling outfit with a larger practitioner base across the country. The orderliness of the industrial waste reverse logistics systems seems to have contributed to the ease with which the NCC was able to make its WEEE guideline.

The clearly identified and committed stakeholders' participation is a key performance indicator of a CE system [21]. Both existing institutional and policy arrangements in the four described cases do not factor in the complete parties in the product production, use, consumption, and disposal. For instance, an interviewed respondent from the water packaging industry noted that "in the water packaging industry, the nylon and the PET bottles used for the water packaging are not produced directly by the majority of the water packaging factories. They are rather outsourced to separate plastic companies." This means that the final user of the waste bottles (for reproduction) in the reverse logistics supply chain system is basically the plastic industry. Therefore, this has created another key opportunity for the meso-level (inter-industry) CE solid waste management planning in the country. Another example is the pulp and paper industry that has a peculiar mode of production, consumption and waste generation. The greater part of the paper products used in the country came through importation, with a low rate of waste collection, while a special variant of the locally produced product (toilet paper) is in high demand and consumption (Figure 4). This requires a critically planned and implemented micro-level CE system design for good results.

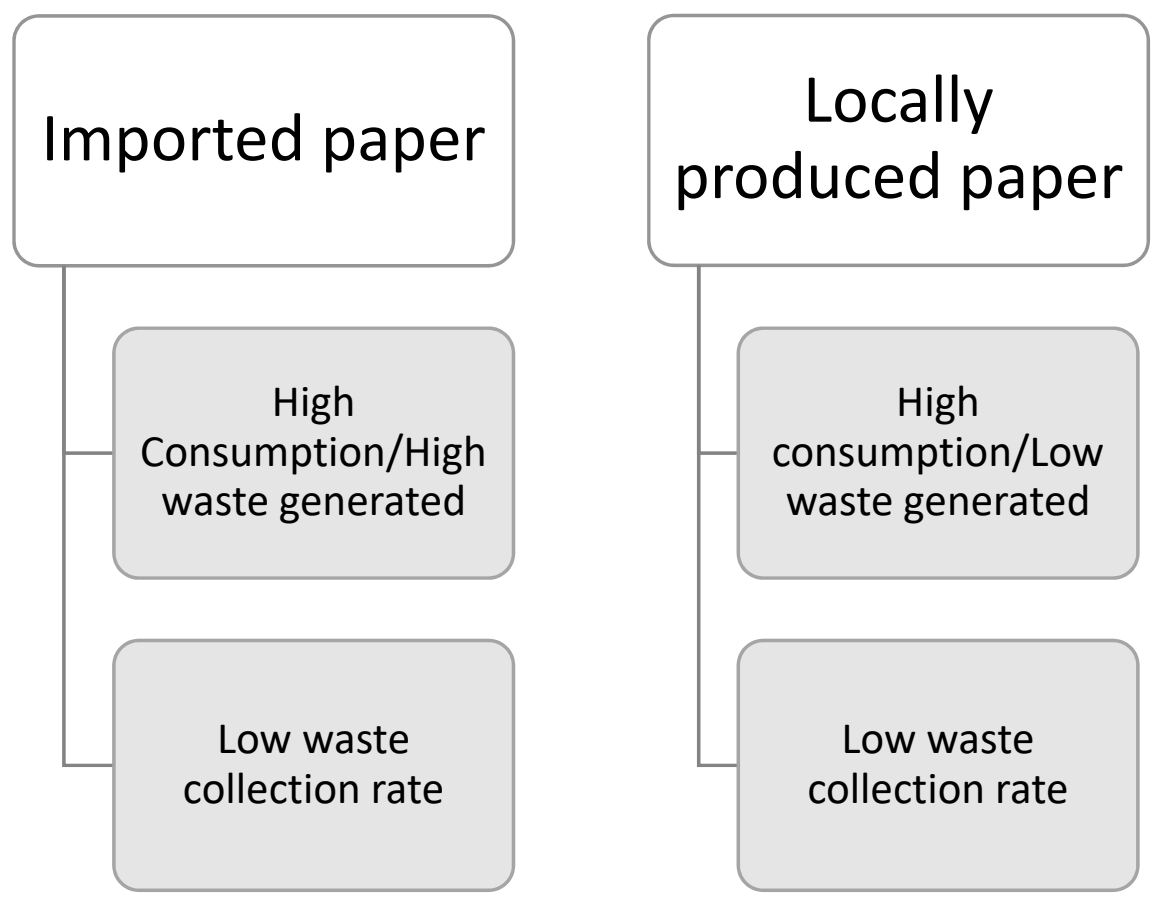

Figure 4. Paper product sources, waste generation, and collection rate. Data Source [28].

The final part of the non-recyclables and non-reusable waste from the studied industries are disposed along with the general municipal solid waste in landfills or dumpsites which is statutorily managed by the state government waste management authorities under which they fall [65]. This has made the state authorities also a stakeholder in the country's industrial solid waste management. In states across the country, the independent waste management authorities supported by their 
respective state governments make laws and collect levies in order to perform this function. The regular practice is to collect this waste and transport them to dumpsites or landfills with little or no due diligence. The unsatisfactory performance of this duty has also been reported across the country caused by the huge quantity of waste to handle and poor financial resources available to the agencies (see Figure 5) [13,22].

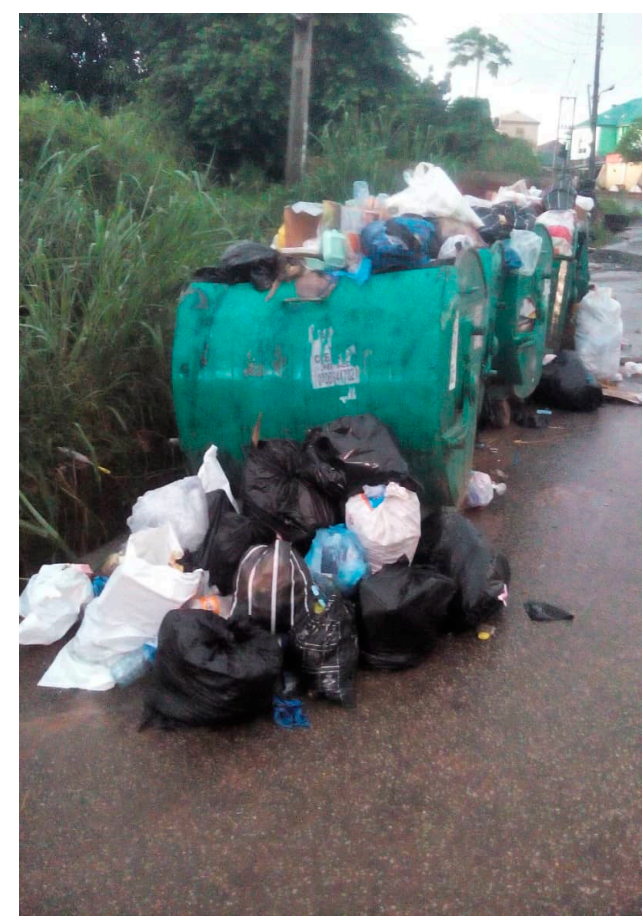

(a)

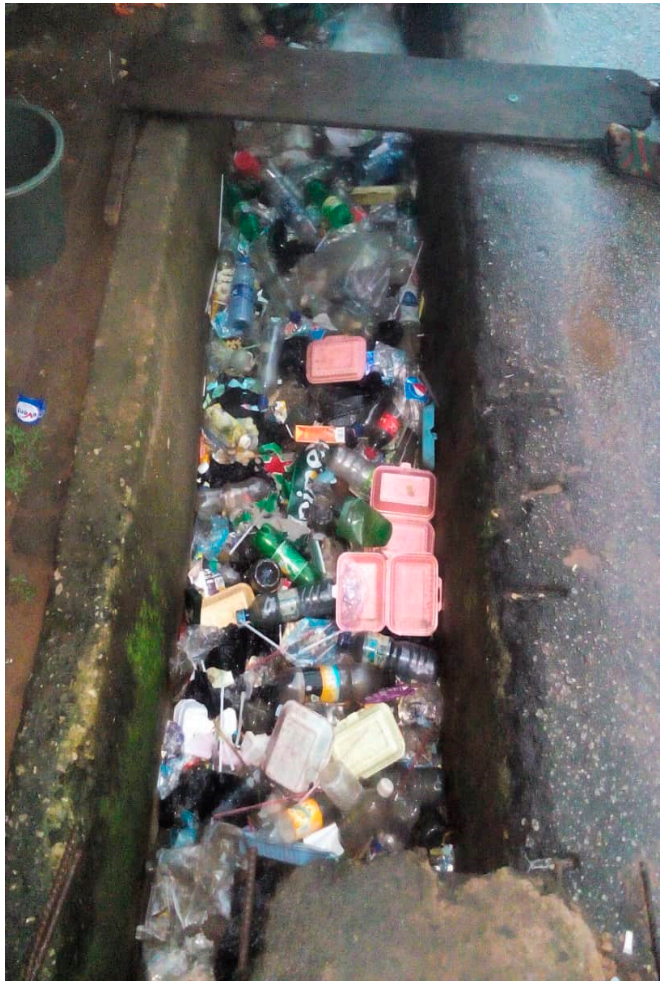

(b)

Figure 5. Municipal solid waste indiscriminately dumped (a) on the street in Nigeria (b) in the water channel.

\section{Future Directions and Conclusions}

The CE as a concept offers huge promise in industrial solid waste management but needs to be well articulated prior to implementation. The key elements of this principle which include the policy and institutional framework, stakeholders' involvement, good waste disposal techniques and the recognition of informal activities need to be well organized in order to yield an optimal result. Having highlighted and discussed issues, the challenges and barriers to the implementation of CE in industrial solid waste management in Nigeria, a number of recommendations are suggested in this paper. The first is that many streams of waste material generated in the Nigerian industries have a proven marketable and reusable ability that could provide profit for the waste producer and the user. Even though the CE framework is non-existent, this practice has been continuing across the industry. The implication is that the basic CE criteria, that proposes multiple lifespans for products while ensuring business profitability, has been met. E-waste, for example, that has been largely regarded as constituting a greater threat to environmental sustainability, also has vast business and economic opportunities. There is one hundred times more gold in a ton of e-waste than in a ton of gold ore, alongside other scarce and valuable materials such as platinum, cobalt and rare earth elements [38]. Therefore, a safe, organized and efficient e-waste recycling has the potential to be a big business venture. The general success and economic and business worth of Nigerian industries have always been underquoted without factoring the additional value that the waste recycling sub-sector 
of each respective industry could add to the gross net worth of the industries. It is recommended that the existing industrial solid waste management system should be overhauled towards achieving this objective. This could start with a reorganization of the regulatory bodies by ensuring that the industrial sector is duly regulated by an independent body, while strengthening their job functions and objectives to also cover the industrial solid waste management. Hence, the policies should be executed in line with CE principles.

Secondly, the role of informal waste recycling activities has been regarded as a key component of the $\mathrm{CE}$ waste valorization system in developing countries [21,65]. Informal waste recycling makes a great contribution to waste resource recovering, job provisioning and by extension, the sustainable urban development. Formalizing the activities is one of the foremost steps in CE implementation in any developing economy. There is evidence of informal waste recycling operations in the vast number of Nigerian industries. It is the authors' opinion that the industrial regulatory agencies could create a place for informal workers in their policy guidelines through incentives, such as providing them with supportive health and safety education and legal backing to operate. The safety issues can also come in the form of ensuring that informal workers have healthy working conditions, safety kits and pension benefits $[21,65]$. Considering the level of poverty and unemployment in the country, there are great prospects for attracting more informal workers when the $\mathrm{CE}$ is formally proclaimed through appropriate policies and incentives. These measures have been repeatedly emphasized in previous research efforts [12,21,65].

Again, what differentiates CE initiatives from regular waste management practices are the introduction of business and economy realities to waste product handling [3]. This study highlighted that most Nigerian industries do not participate actively in the final disposal of their solid waste. Although they pay levies to the government authorities that solely perform this function. However, the so-called levies are not often apportioned according to the quantity, character or nature of the generated waste. If measures are introduced where the levies are distributed according to aforementioned criteria, it would hasten effort by the waste generating firms to minimize their disposable waste. Further, this could create consciousness among industries so they make an effort to sell their recyclables/reusables in order to generate funds to finance the ones they are disposing.

There is equally a need for the stakeholders to embark on aggressive mass education as the general Nigerian public is yet to contemplate waste as a means of wealth generation but rather it is still regarded as all rubbish that needs to be discarded [28]. This has affected the public attitude to waste collection and the scavengers. Nevertheless, for CE at any level to work optimally, there should be modalities for identifying the whole stakeholders with clearly defined functions and roles [69]. One way to do this is to clearly articulate the forward and reverse logistics in the product supply chain management at the industrial level in the policies.

Author Contributions: O.B.E. conceptualized, investigated and wrote the original manuscript. O.B.E. curated and formally analyzed the research data. O.B.E. and T.S.E. revised and edited the manuscript.

Funding: This research received no external funding.

Acknowledgments: The authors gratefully acknowledge the support received from UNN-SHELL Centre for Environmental Management and Control and Institute for Development Studies, University of Nigeria, Enugu Campus. We also acknowledge the authors whose works were useful in this research.

Conflicts of Interest: The authors declare no conflicts of interest.

\section{References}

1. Ellen MacArthur Foundation. Concept: What is Circular Economy? A Framework for an Economy That is Restorative and Regenerative by Design. Available online: https://www.ellenmacarthurfoundation.org/ circular-economy/concept (accessed on 9 September 2019).

2. Onipede, A.I.; Bolaji, B.O. Management and disposal of industrial waste in Nigeria. Niger. J. Mech. Eng. 2004, 2, 49-58. 
3. Romero-Harnendez, O.; Romero-Harnendez, S. Maximizing the value of waste: From waste management to circular economy. Thunderbird Int. Bus. Rev. 2018, 60,757-764. [CrossRef]

4. Mathews, J.A.; Tan, H. Progress toward a circular economy in China. J. Ind. Ecol. 2011, 15, 435-475. [CrossRef]

5. Lehmann, M.; Leeuw, B.D.; Fehr, E.; Wong, A. Circular Economy. Improving the Management of Natural Resources; World Resource Forum: Bern, Switzerland, 2014.

6. Xue, B.; Chen, X.P.; Geng, Y.; Guo, X.J.; Lu, C.P.; Zhang, Z.L.; Lu, C.Y. Survey of officials' awareness on circular economy development in China: Based on municipal and county level. Resour. Conserv. Recycl. 2010, 54, 1296-1302. [CrossRef]

7. Su, B.; Heshmati, A.; Geng, Y.; Yu, X. A review of the circular economy in China: Moving from rhetoric to implementation. J. Clean. Prod. 2013, 42, 215-227. [CrossRef]

8. Singh, J.; Ordonez, I. Resource recovery from post-consumer waste: Important lessons for the upcoming circular economy. J. Clean. Prod. 2016, 134, 342-353. [CrossRef]

9. Ngan, S.L.; How, B.S.; Teng, S.W.; Promentilla, M.A.B.; Yatim, P.; Er, A.C.; Lam, H.L. Prioritization of sustainability indicators for promoting the circular economy: The case of developing countries. Renew. Sustain. Energy Rev. 2019, 111, 314-331. [CrossRef]

10. Ogunmakinde, O.E. A review of circular economy development models in China, Germany and Japan. Recycling 2019, 4, 27. [CrossRef]

11. Zhijun, F.; Nailing, Y. Putting a circular economy into practice in China. Sustain. Sci. 2007, 2, 95-101. [CrossRef]

12. Scarlet, N.; Motola, V.; Dallemand, J.F.; Monforti-Ferrario, F.; Mofor, L. Evaluation of energy potential of municipal solid waste from African urban areas. Renew. Sustain. Energy Rev. 2015, 50, 1269-1286. [CrossRef]

13. Agunwamba, J.C. Analysis of scavengers activities and recycling in some cities of Nigeria. Environ. Manag. 2003, 32, 116-127. [CrossRef]

14. Plastinina, I.; Teslyuk, L.; Dukmasova, N.; Pikalova, E. Implementation of circular economy principles in regional solid municipal waste management: The case of Sverdlovskaya Oblast (Russian Federation). Resources 2019, 8, 90. [CrossRef]

15. Kiørboe, N.; Sramkova, H.; Krarup, M. Moving Towards a Circular Economy: Successful Nordic Business Models; Nordic Council of Ministers: Copenhagen, Denmark, 2015.

16. Sariatli, F. Linear economy versus circular economy: A comparative and analyzer study for optimization of economy for sustainability. Visegrad J. Bioeconomy Sustain. Dev. 2017, 6, 31-34. [CrossRef]

17. European Commission. Towards a Circular Economy: A Zero Waste Programme for Europe. Brussels, 2.7.2014 COM(2014) 398 Final. Available online: https://ec.europa.eu/environment/circular-economy/pdf/ circular-economy-communication.pdf (accessed on 8 September 2019).

18. Lahti, T.; Wincent, J.; Parida, V. A definition and theoretical review of the circular economy, value creation, and sustainable business models: Where are we now and where should research move in future? Sustainability 2018, 10, 2799. [CrossRef]

19. Korhonen, J.; Honkasalo, A.; Seppala, J. Circular economy: The concept and its limitation. Ecol. Econ. 2018, 143, 37-46. [CrossRef]

20. Kirchherr, J.; Reike, D.; Hekkert, M. Conceptualizing the circular economy: An analysis of 114 definitions. Resour. Conserv. Recycl. 2017, 127, 221-232. [CrossRef]

21. Ferronato, N.; Rada, E.C.; Portillo, M.A.G.; Cioca, L.I.; Ragazzi, M.; Torrenta, V. Introduction of the circular economy within developing regions: A comparative analysis of advantages and opportunities for waste valorization. J. Environ. Manag. 2019, 230, 366-378. [CrossRef]

22. Abila, B.; Kantola, J. Municipal solid waste management problems in Nigeria: Evolving knowledge management solution. Int. J. Environ. Ecol. Eng. 2013, 7, 6.

23. Asthana, D.K. Text Book of Environmental Studies; S. Chand \& Company Ltd.: New Delhi, India, 2006 ; p. 397.

24. Van der Elst, K.; Williams, A. Industry 4.0: The New Production Paradigm and Its Implication For EU Policy. European Union. 2017. Available online: file://C:/Users/user/Downloads/Industry\%204.0\%20-\%20The\% 20new\%20production\%20paradigm\%20and\%20its\%20implications\%20for\%20EU\%20policy.pdf (accessed on 11 September 2019). 
25. Miner, C.A.; Tagurum, Y.O.; Hassan, Z.; Afolaranmi, T.O.; Bello, D.A.; Dakhin, A.; Zoakah, A.I. Sachet Water: Prevalence of Use, Perception, and Quality in a Community of Jos Local Government Area of Plateau State. African Journal Online. Available online: https://www.ajol.info/index.php/jjm/article/viewFile/138960/128663 (accessed on 4 September 2019).

26. Dada, A.C. Packaged water: Optimizing local processes for sustainable water delivery in developing nations. Glob. Health 2011, 7, 24. [CrossRef]

27. Saidani, M.; Yannou, B.; Leroy, Y.; Cluzel, F. How to access product performance in the circular economy? Proposed requirements for the design of a circularity measurement framework. Recycling 2017, 2, 6. [CrossRef]

28. Ezeudu, O.B.; Agunwamba, J.C.; Ezeasor, I.C.; Madu, C.N. Sustainable production and consumption of paper and paper product in Nigeria: A review. Resources 2019, 8, 53. [CrossRef]

29. Population Reference Bureau. 2018. Available online: https://www.prb.org/wp686content/uploads/2018/08/ 2018_WPDS.pdf (accessed on 6 September 2019).

30. Udeala, S.O. Nigeria-China economic relations under South-South Cooperation. Afr. J. Int. Aff. 2010, 13, 61-88.

31. Agbu, O. Promoting Nigeria-China relation. Niger. Forum 1994, 14.

32. Chen, S.; Ravallion, M. The developing world is poorer than we thought, but no less successful in the fight against poverty. Q. J. Econ. 2010, 125, 1577-1625. [CrossRef]

33. Environmental and Public Health Watch. Policy Guidelines on Solid Waste Management 2005. Developed by Federal Ministry of Environment Abuja. Available online: https://tsaftarmuhalli.blogspot.com/2011/12/ policy-guidelines-on-solid-waste.html (accessed on 9 September 2019).

34. Idowu, I.A.; Atherton, W.; Hashim, K.; Kot, P.; Alkhaddar, R.; Alo, B.I.; Shaw, A. An analyses of the status of landfill classification systems in developing countries: Sub Sahara Africa landfill experiences. Waste Manag. 2019, 87, 761-771. [CrossRef]

35. Regassa, N.; Sundaraa, R.D.; Seboka, B.B. Challengies and opportunities in municipal solid waste management:the case of addis abbba city, central Ethiopia. J. Hum. Ecol. 2011, 33, 179-190. [CrossRef]

36. Adeniran, A.A.; Adewole, A.A.; Olofa, S.A. Impact of solid waste management in Ado-Ekiti property values. Civil. Environ. Res. 2014, 6, 29-35.

37. Sridhar, M.K.C.; Oluborode, J.A.; Uwadiegwu, Z. Waste management policy and implementation in Nigeria. Natl. J. Adv. Res. 2017, 3, 23-35.

38. United Nations Environment Programme (UNEP). Nigeria Turns the Tide on Electronic Waste. Published 19 June 2019. Available online: https://www.unenvironment.org/news-and-stories/press-release/nigeria-turnstide-electronic-waste (accessed on 12 September 2019).

39. Patton, M.Q. Qualitative Research and Evaluation Methods, 3rd ed.; Sage: Thousand Oaks, CA, USA, 2001.

40. Strauss, A.; Corbin, J. Basics of Qualitative Research: Techniques and Procedures for Developing Grounded Theory; Sage: Thousand Oaks, CA, USA, 2007.

41. Van Maanen, J. Reclaiming qualitative methods for organizational research: A preface. Adm. Sci. 1979, 24, 520-526. [CrossRef]

42. Yin, R.K. Case Study Research: Design and Method; Sage: Thousand Oaks, CA, USA, 1983.

43. Kuo, A. Harnessing frugal innovation to foster clean technologies. Clean Technol. Environ. Policy 2017, 19, 1109-1120. [CrossRef]

44. Lincoln, Y.S.; Guba, E.G. Naturalistic Inquiry; Sage: Beverly Hill, CA, USA, 1985; Volume 75.

45. Glaser, B.G.; Strauss, A.L. The Discovery of Grounded Theory: Strategies for Qualitative Research; Aldine Transaction: Piscataway, NJ, USA, 1967; Rutgers.

46. Noda, T.; Bower, J.L. Strategy making as iterative processes of resource allocation. Strateg. Manag. J. 1996, 17, 159-192. [CrossRef]

47. Denzin, N.K.; Lincoln, Y.S. The Sage Handbook of Qualitative Research, 3rd ed.; Sage: London, UK, 2005.

48. Miles, M.B.; Huberman, A.M. Qualitative Data Analysis. A sourcebook of New Methods; Sage: Beverly Hills, CA, USA, 1984.

49. Ndukwe, E. Country Experience in Telecom Market Reforms-Nigeria. 2005. Available online: https://www.ncc.gov.ng/archived/speeches/Country\%20Experience\%20with\%20Market\%20Reforms\% 20in\%20Telecoms\%20\%20-\%20060705..pdf (accessed on 10 September 2019). 
50. Proshare Intelligent Investing: The Nigerian Telecommunication Sector- Challenges and Cautious Optimism. 2017. Available online: https://www.proshareng.com/news/Mobile-Money-and-Telcos/The-NigerianTelecommunication-Sector---/36424 (accessed on 10 September 2019).

51. GSMA, Spotlight on Nigeria: Delivering a Digital Future. 2018. Available online: https://www. gsma.com/publicpolicy/wp-content/uploads/2019/02/GSMA-Spotlight-on-Nigeria-Report.pdf (accessed on 10 September 2019).

52. Nkordeh, N.; Bob-Manuel, I.; Olowononi, F. The Nigerian telecommunication industry: Analysis of the first fifteen years of the growths and challenges in the GSM market (2001-2016). In Proceedings of the World Congress on Engineering and Computer Science (WCECS 2017), San Francisco, CA, USA, 25-27 October 2017; Volume 1.

53. Osibanjo, O.; Nnorom, I.C. The challenges of electronic waste (e-waste) management in developing countries. Waste Manag. Res. 2007, 25, 489-501. [CrossRef] [PubMed]

54. Wlliams, E.D. Extending PC lifespan through secondary markets. In Proceedings of the 2003 IEEE International Symposium on Electronics and the Environment, Washington, DC, USA, 19-22 May 2003; pp. 255-259.

55. Balde, C.P.; Wang, F.; Kuehr, R.; Huisman, J. The Global E-waste Monitor, 2014: Quantities, Flows and Resources; A Report; United Nations University, UNU-IAS, Institute for Advanced Study Sustainability: Bonn, Germany, 2015; pp. 1-74.

56. Williams, E. International activities on E-waste and guidelines for future works. In Proceedings of the Third Workshop on Materials Cycles and Waste Management in Asia; National Institute of Environmental Sciences: Tsukuba, Japan, 2005; Available online: https://www.academia.edu/759160/International_activities_on_Ewaste_and_guidelines_for_future_work (accessed on 12 September 2019).

57. Ogungbuyi, O.; Nnorom, I.C.; Osibanjo, O.; Schluep, M. E-Waste Country Assessment Nigeria: A Report, E-Waste Africa Project of the Secretariat of the Basel Convention; Secretariate of Basel Convention: Geneva, Switzerland, 2012.

58. Manhart, A.; Osibanjo, O.; Aderinto, O.; Prakash, S. Informal E Waste Management in Lagos, Nigeriasocio-Economic Impacts and Feasibility of Inter-National Recycling Cooperations: Final Report of Component 3 of the UNEP SBC E-Waste Africa Project; Öko-Institut eV \& University of Ibadan, Freiburg \& Lagos: Freiburg, Germany, 2011.

59. Nigerian Communication Commission. Nigerian Communication Industry E-Waste Regulation. 2018. Available online: https://www.ncc.gov.ng/documents/823-draft-regulations-on-e-waste/file (accessed on 12 September 2019).

60. Nigerian Investment Promotion Commission: Nigeria's Food Industry Worth Over \$ 3.2 Billion. 2016. Available online: https://nipc.gov.ng/2016/10/22/nigerias-food-industry-worth-3-2-billion/ (accessed on 9 September 2019).

61. Taiwo, K.A.; Oladepo, O.W.; Ilori, M.O.; Akanbi, C.T. A study of Nigerian food industry and the impact of technological changes on the small-scale food enterprises. Food Rev. Int. 2002, 18, 243-261. [CrossRef]

62. Oladepo, O.W.; Ilori, M.O.; Taiwo, K.A. Assessment of waste generation and management practices in Nigerian food Industry: Towards a policy for sustainable approaches. Am. J. Sci. Ind. Res. 2014, 6, 12-22.

63. Food and Agriculture Organization. Street Food Report of a FAO Expert Consultation, (Meeting No 46); FAO Food Nutition. India: Jogjarkata, Indonesia, 1990.

64. Ezeudu, O.B.; Ozoegwu, C.G.; Madu, C.N. A statistical regression method for characterization of household solid waste: A case study of Awka municipality in Nigeria. Recycling 2019, 4, 1. [CrossRef]

65. Nzeadibe, T.C. Solid waste reforms and informal recycling in Enugu urban area, Nigeria. Habitat Int. 2009, 33, 93-99. [CrossRef]

66. Edoga, M.O.; Onyeji, L.I.; Oguntosin, O.O. Achieving vision 20: 2020 through waste produce candle. J. Eng. Appl. Sci. 2008, 3, 642-646.

67. Adekunle, L.V.; Sridhar, M.K.C.; Ajayi, A.A.; Oluwade, P.A.; Oluwuyi, J.F. An assessment of the health and socio-economic implications of sachet water in Ibadan Nigeria: A public health challenge. Afr. J. Biomed. Res. 2004, 7, 5-8. 
68. RMRDC. National Strategy for Competitiveness in Raw Material and Product Development in Nigeria; RMRDC: Abuja, Nigeria, 2016; p. 266.

69. Geissdoerfer, M.; Savaget, P.; Bocken, N.M.; Hultink, E.J. The Circular Economy-A sustainability paradigm? J. Clean Prod. 2016, 143, 757-768. [CrossRef] 